\title{
FAMILIAL CROUZON'S SYNDROME WITH PATENT DUCTUS ARTERIOSUS: A RARE COINCIDENCE
}

Budhi Prakash Bhatia ${ }^{1}$, Vinod Kumar², Jaiveer Singh Shekhawat ${ }^{3}$, Vinay Naithani ${ }^{4}$

\section{HOW TO CITE THIS ARTICLE:}

Budhi Prakash Bhatia, Vinod Kumar, Jaiveer Singh Shekhawat, Vinay Naithani. "Familial Crouzon's Syndrome with Patent Ductus Arteriosus: A Rare Coincidence". Journal of Evolution of Medical and Dental Sciences 2014; Vol. 3, Issue 57, October 30; Page: 13050-13053, DOI: 10.14260/jemds/2014/3734

ABSTRACT: Recently we operated a case of large patent ductus arteriosus (PDA). On clinical examination and radiological investigation patient has features of rare Crouzon's syndrome. Familial affection are usually mother and her daughter but in this case father and not mother affected. Being a rare anomaly and has association with cardiac anomaly and familial tendency, we feel it is worth to report this patient.

KEYWORDS: Patent ductus arteriosus, Crouzon's syndrome, Branchial arch syndrome, Genetic disorder.

INTRODUCTION: Crouzon's syndrome is a developmental anomaly of first branchial arch. It is a rare anomaly affecting mainly skull face with prognanthism, low set ear with hearing loss, high arch palate and cardiac anomalies mainly PDA. ${ }^{(1,2,3)}$ It is an autosomal dominant with genetic mutation and may have familial tendency. $(3,4,5,6,7)$

CASE REPORT: A 9 year old female child with body weight of $14 \mathrm{~kg}$ and height of $105 \mathrm{~cm}$ presented with repeated respiratory tract infection and failure to thrive. On general examination she has broad forehead prominent bulging eyes, prognathia, low lying external ears, high arch palate deformity, mental retardation, deafness and growth retardation with associated kyphoscoliosis.

FAMILY HISTORY: Father has similar facial deformity but no other anomalies. Cardiac examination shows apex at $6^{\text {th }}$ intercostal space mid clavicular line. S1 normal P2 loud, There was continuous machinery murmur infraclavicular and pulmonary region. ECG Normal sinus rhythm, normal axis, $p$ mitral, Left Ventricular (LV) hypertrophy, incomplete LBBB. X ray chest- Kyphoscoliosis deformity present CTR $>50 \%$ LV apex, Aortic Knuckle prominent Pulmonary conus prominent pulmonary plethora present. 2D Echo- Large patent ductus arteriosus with dilated Left Atrium, LV normal function.

OPERATIVE DETAIL: Patient was taken for PDA closure. PDA double ligation was performed via left posterolateral thoracotomy approach. PDA was dissected retro pleurally, it was large and of size of descending aorta. Under hypotensive anaesthesia it was looped twice and ligated. Drain kept, chest closed in layers. Patient extubated shifted to ICU and did well postoperatively.

DISCUSSION: This congenital anomaly was named after Octave Crouzon, (8) a French physician. It is caused by mutation in fibroblast growth factor receptor II located on chromosome $10 .(3,4,5,6,7)$ Incidence of crouzon's syndrome is currently estimated to occur in 1.6 out of every 1,00,000 people.(6) There is a great frequency in families with a history of the disorder, but that does not mean that 


\section{CASE REPORT}

everyone in the family is affected. Diagnosis can occur with sign and symptom, clinical examination, radiograph, magnatic resonance imaging scan, genetic testing, CT scan and diagnosis of associated anomalies like cardiac with 2D Echo. It is an autosomal dominant genetic disorder(8) known as a branchial arch syndrome affect first branchial arch mainly affecting maxilla and mandible.(1,7) Low set ears, ear canal malformation with hearing loss and in severe cases Meniere's disease may occur.

Craniosynostosis $(2,9)$ with short and broad head, Exophthalmos, hypertelorism (greater than normal distance between eyes), Psittichorhina (beak like nose), Hypoplastic maxilla (insufficient growth of mid face) result in prognathism (chin appears to protrude despite normal growth of mandible).(2,8,9) It is associated with PDA and aortic coarctation.(9) Other anomalies are shorter humerus and femur to rest of body. A small percentage has partial syndactyly. Oral and maxillofacial, dental, plastic, and associated cardiac surgery help patient.(1,2,3)

\section{REFERENCES:}

1. Britto JA, Greig A, Abela C, Hearst D, et al. "Frontofacial surgery in children and adolescents: techniques, indications, outcomes." 2014; 28(3):121-9.

2. Song H, Park MC, Lee IJ, Park DH, et al. "Correction of infraorbital and malar deficiency using costal osteochondral graft along with orthognathic surgery in crouzon syndrome. 2014; 25(5): 449-51.

3. Vajo Z, Francomano CA, Wilkin DJ et al. "The molecular and genetic basis of fibroblast growth factor receptor 3 disorders: the achondroplasia family of skeletal dysplasias, muenkecraniosynostosis, and Crouzon's syndrome with acanthosisnigricans". Endocrine Reviews. 2000; 21 (1):23-39.

4. Meyers GA, Orlow SJ et al. "Fibroblast growth factor receptor 3(FGFR) transmembrane mutation in crouzon's syndrome with acanthosisnigricans".Nature Genetic 1995; 11(4): 462-4.

5. Reardon W, Winter RM, Ruthland et al. "Mutations in fibroblast growth factor receptor 2 gene cause crouzon's syndrome". Nature Genetic 1994; 8 (1): 98-103.

6. Robin, NH; Falk, MJ; Haldeman-Englert, CR et al. "FGFR-Related Craniosynostosissyndromes. Gene Reveiws $^{\mathrm{R}}$ [Internet]. Seattle (WA): University of washington, Seattle; 1993-2014.

7. Warman, M.L., Mulliken, J.B. et al."newly recognised autosomal dominant craniosynostotic syndrome”. Am.J.med. Genetic. 1993; 46: 444-449.

8. L.E.O. Crouzon. Dysostosecranio-facialehe/re/ditaire. Bulletin de la Socie/te/ des Me/decins des Ho^pitaux de Paris, 1912; 33: 545-555.

9. Gorlin RJ, Chaudhry AP, Moss ML, et al "Craniofacial dysostosis, patent ductusarteriosus, hypertrichosis, hypoplasia of labia majora, dental and eye anomalies-a new syndrome? 1960; 56: 778-85. 


\section{CASE REPORT}

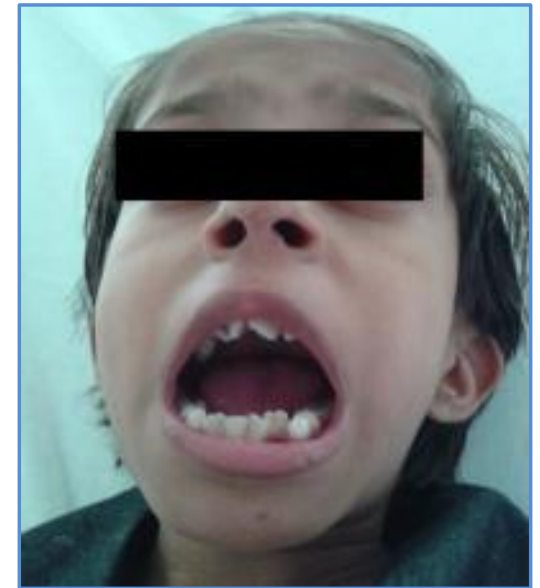

Fig. 1: Abnormal denture and High arched palate

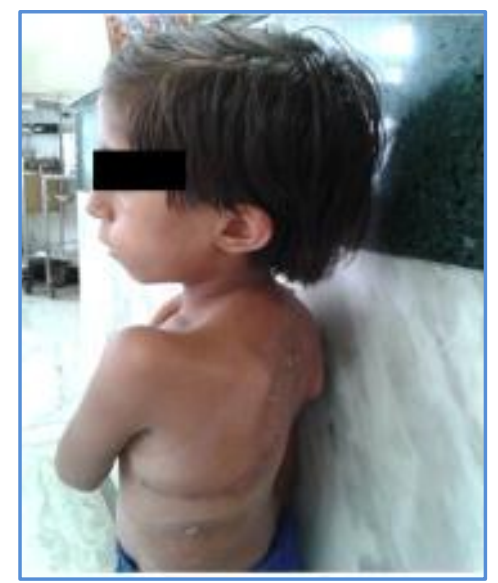

Fig. 3: Postoperative scar of PDA closure

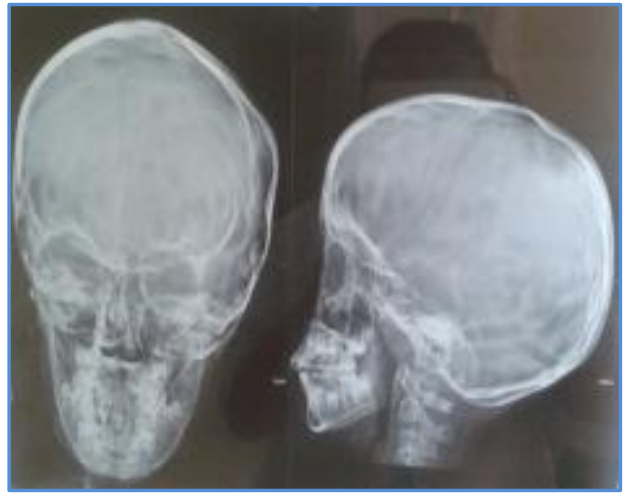

Fig. 5: X-RAY skull AP and Lateral

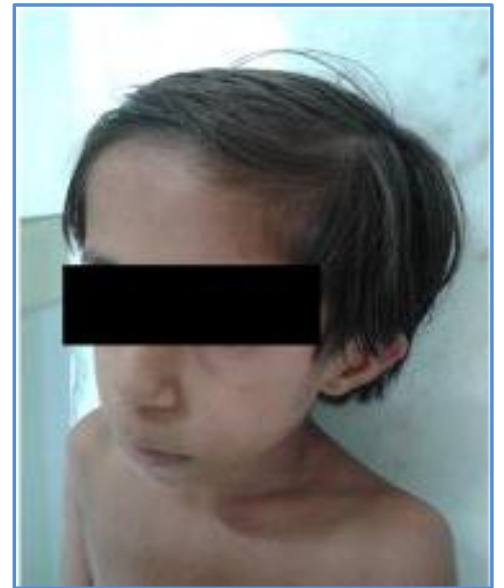

Fig. 2: Hypertelorism, Low set ears, broad Fore head

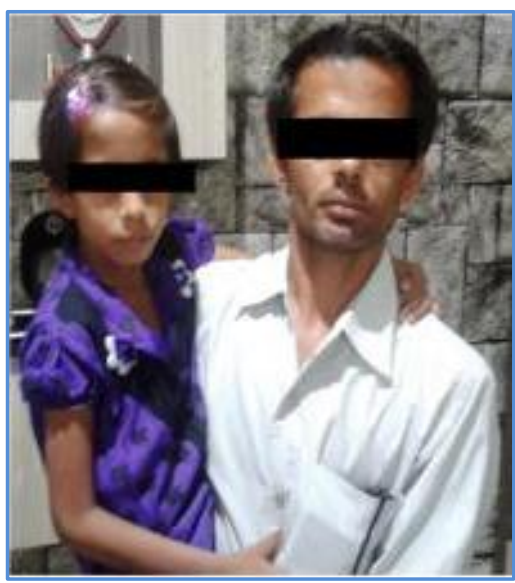

Fig. 4: The patient with her father 


\section{CASE REPORT}

\section{AUTHORS:}

1. Budhi Prakash Bhatia

2. Vinod Kumar

3. Jaiveer Singh Shekhawat

4. Vinay Naithani

\section{PARTICULARS OF CONTRIBUTORS:}

1. Second Year Mch Resident, Department of Cardiothoracic \& Vascular Surgery, RNT Medical College, Udaipur, Rajasthan, India.

2. Post Graduate Student, Department of General Surgery, RNT Medical College, Udaipur, Rajasthan, India.

3. Post Graduate Student, Department of General Surgery, RNT Medical College, Udaipur, Rajasthan, India.
4. Senior Professor \& HOD, Department of Cardiothoracic \& Vascular Surgery, RNT Medical College, Udaipur, Rajasthan, India.

\section{NAME ADDRESS EMAIL ID OF THE CORRESPONDING AUTHOR:}

Dr. Vinay Naithani,

Senior Professor \& HOD,

Cardiothoracic \& Vascular Surgery, \# 68, Adinath Nagar, Jagat Mehta Ki Bari,

Fatehpura, Udaipur, Rajasthan, India-313001.

Email: drvinaynaithani@yahoo.co.in

Date of Submission: 14/10/2014.

Date of Peer Review: 15/10/2014.

Date of Acceptance: 25/10/2014.

Date of Publishing: 30/10/2014. 